\title{
NATURAL SELECTION IN TWO COLONIES OF THE POLYMORPHIC LAND SNAIL CEPAEA NEMORALIS
}

\author{
P. M. SHEPPARD \\ Genetics Loboratory, Deportment of Zoology, Oxford

\section{CONTENTS}

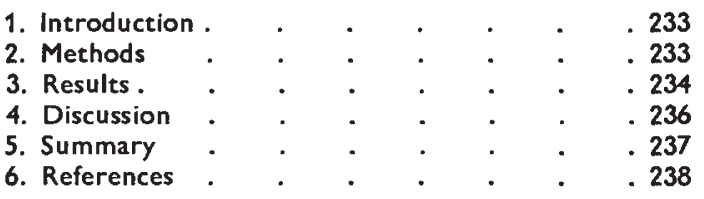

Received 25.ix.5I

\section{INTRODUCTION}

IT has been shown by Lang (1908 and 1912) and Fisher and Diver (1934) that the colour and banding patterns on the shell of the snail Cepaea nemoralis (L) are genetically determined. Diver (1940) not only found that colonies of the snails differ in the proportions of the varieties in them, but also that the ratio of the phenotypes may not be the same in all areas of a single colony. He maintained that this is the result of isolation by distance and sampling errors in reproduction, a process which is considered to be of great evolutionary importance by Wright (e.g. 1940). Cain and Sheppard (1950) and Sheppard (1951) on the contrary demonstrated that the various patterns have different selective values, and that their proportions, in any colony, are the result of natural selection; however, they did not preclude the possibility that small inbreeding communities might not diverge to some extent as the result of "genetic drift".

The present paper is an account of an investigation of a single colony of $C$. nemoralis and a comparison of this population with another, a mile away, which was first studied by Cain and Sheppard (1950).

\section{METHODS}

\section{(i) Collecting}

Samples of the shells of adult snails were taken from two colonies of $C$. nemoralis at Rockley and Rough Down near Marlborough, Wiltshire. To ensure that the collections were random, all the adult individuals that could be found were collected from several small areas in each population.

\section{(ii) Recording}

The colour and banding pattern of each shell was recorded using the method described by Cain and Sheppard (1950). 


\section{RESULTS}

The results of collecting in the two colonies are given in tables I and 2. The samples from Rockley were taken from nine localities in

TABLE I

\begin{tabular}{|c|c|c|c|c|c|c|c|c|c|c|c|}
\hline \multirow[b]{2}{*}{ Locality } & \multicolumn{4}{|c|}{ Yellow } & \multicolumn{4}{|c|}{ Pink } & \multicolumn{3}{|c|}{ Brown } \\
\hline & $\frac{\frac{8}{0}}{\frac{d}{0}}$ & $\frac{\frac{19}{2}}{8}$ & : & $\begin{array}{l}: \\
:\end{array}$ & 㟧 & $\frac{\text { के }}{8}$ & \&े & 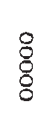 & 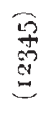 & $\frac{8}{8}$ & $\begin{array}{l}: \\
\vdots \\
8\end{array}$ \\
\hline Rockley I & - & - & 5 & I & 一 & - & I & 4 & I & I & 8 \\
\hline Rockley 2 & - & - & 16 & เ8 &.-- & - & 7 & $5^{\mathrm{I}}$ & - & 2 & 45 \\
\hline Rockley 3 & - & - & Io & 15 & - & - & 4 & 20 & - & - & 21 \\
\hline Rockley 4 & - & - & 17 & 22 & - & - & 10 & 19 & - & ‥- & $4^{2}$ \\
\hline Rockley 5 & I & - & $4^{8}$ & $5 \mathrm{I}$ & - & - & II & 25 & - & 2 & 63 \\
\hline Rockley 6 & - & - & 4 & 9 & $\ldots$ & --- & I9 & 8 & - & - & 43 \\
\hline Rockley 7 & - & I & 7 & 7 & - &.- & 3 & 4 & 一 & I & Ii \\
\hline Rockley 8 & - & - & 4 & 2 & I & - & 4 & 6 & - & I & 12 \\
\hline Rockley 9 & - & - & 3 & I & - & I & 6 & 2 & - & 3 & 9 \\
\hline
\end{tabular}

TABLE 2

\begin{tabular}{|c|c|c|c|c|c|c|c|c|c|c|c|c|c|c|c|c|c|c|c|c|c|c|c|}
\hline \multirow[b]{2}{*}{ Locality } & \multicolumn{8}{|c|}{ Yellow } & \multicolumn{9}{|c|}{ Pink } & \multicolumn{6}{|c|}{ Brown } \\
\hline & 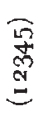 & $\underset{\text { ஸे }}{\stackrel{\text { ஸे }}{0}}$ & 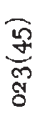 & $\frac{n}{\stackrel{0}{0}}$ & $\frac{5}{8}$ & $\frac{8}{\stackrel{8}{0}}$ & $\begin{array}{l}0 \\
8 \\
8\end{array}$ & $\begin{array}{l}8 \\
8 \\
8\end{array}$ & 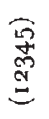 & $\frac{\text { m }}{\text { ले }}$ & 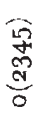 & $\frac{\text { mे }}{8}$ & $\frac{\sqrt{7}}{8}$ & $\frac{5}{8}$ & 官 & $\begin{array}{l}8 \\
8 \\
8\end{array}$ & $\begin{array}{l}8 \\
8 \\
8\end{array}$ & $\begin{array}{l}\widetilde{\Omega} \\
\text { ले } \\
\text { v }\end{array}$ & $\frac{\mathfrak{n}}{\stackrel{5}{2}}$ & $\frac{\frac{10}{ \pm}}{\frac{10}{0}}$ & 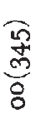 & $\begin{array}{l}\text { g } \\
\text { ले } \\
\text { o }\end{array}$ & 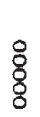 \\
\hline Rough Down I 949 & 5 & - & - & $\rightarrow$ & I & - & $2 \mathrm{I}$ & 47 & - & $\mathbf{I}$ & - & 2 & 2 & $\mathbf{I}$ & $\mathbf{I}$ & I 3 & 5 & 3 & I & $\mathbf{I}$ & - & I I & 49 \\
\hline Rough Down I $95^{\circ}$ & 5 & - & $\mathbf{I}$ & - & - & I & 9 & 29 & I & - & - & - & - & - & - & 2 & I & - & - & - & - & - & I 8 \\
\hline Rough Down I 95 I & - & $\mathbf{I}$ & - & I & - & - & 5 & $3 \mathbf{I}$ & - & $\mathbf{I}$ & I & I & - & - & - & 7 & I & - & - & - & I & 5 & 24 \\
\hline Total & 6 & $\mathbf{I}$ & $\mathbf{I}$ & $\mathbf{I}$ & $\mathbf{I}$ & I & 35 & 107 & I & 2 & I & 3 & 2 & I & I & 22 & 7 & 3 & I & I & $\mathbf{I}$ & I 6 & 9 I \\
\hline
\end{tabular}

a large area, all of which is inhabited by the snail (fig. I). Three collections were obtained from Rough Down. The first was taken in I949 (Cain and Sheppard, I950), the second in I950 and the third in I $95^{\mathrm{I}}$ at the same time as those from Rockley.

(i) Description of the Rockley localities

I. The area is covered by a thick plantation of beech trees with a carpet of beech cupules and small patches of exposed soil. There is also a quantity of sparse grass and herbs.

2. This locality is a continuation of the first but is on a steep slope and consequently much dryer. It has less green vegetation and there are large quantities of dry brown beech leaves on the ground as well as brown cupules.

3. The third station is a continuation of this wood. It becomes very narrow and ends as a single row of trees where it joins the sixth 
locality. This narrow plantation has a thick carpet of grass with very few beech leaves or cupules. It is intermediate in type between the wood and green downland habitats.

4. The fourth locality is an open downland to the south-east of the second collecting station. For most of the year it has tussocks of short grass which have been flattened by the wind to give a smooth green carpet. However, since sheep no longer graze here the grass becomes quite long in late summer. The down is near a beech wood and consequently has a number of beech leaves between the tussocks. It is therefore intermediate in type between beech wood and downland.

5. The fifth area is a continuation of the preceding locality. It is an open downland habitat with exactly the same vegetation as the fourth station but with no beech leaves on it as it is further from the wood.

6. The snail population in the sixth locality is living under a very overgrown beech hedge which is about twenty feet high and ten feet wide. Both the grass field to the north of the hedge and the cart track to the south are unsuitable for $C$. nemoralis and one not permanently inhabited by it. The ground under the hedge is devoid of vegetation over considerable areas, but there are patches of grass wherever there are few branches near the ground or where there are gaps between the bushes.

7. To the south of the beech hedge and east of the large beech wood (area 9) there is a continuous stretch of downland which surrounds a triangular plantation. For most of the year this downland is covered by tussocks of medium length grass which has been flattened by the wind to give a smooth green carpet.

8. In area 7, about 60 yards to the south of the hedge, near its northern end, there is a small triangular beech plantation. This has a carpet of beech leaves very similar to area 2 .

9. A hundred yards west of the triangular copse there is a large beech wood with a carpet of litter very like that found in the preceding locality.

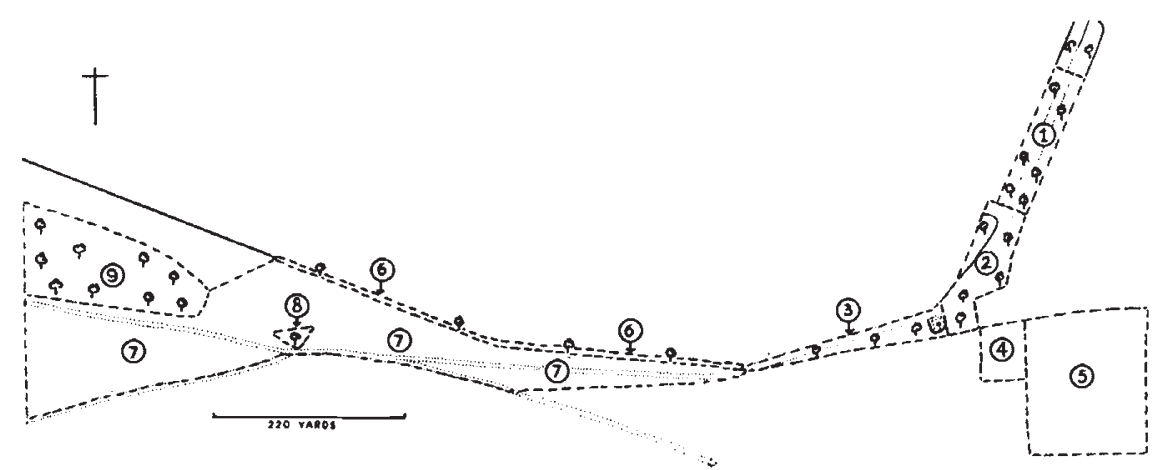

FIG. 1.-Sketch map showing the collecting localities at Rockley. Broken lines mark their boundaries. The woods are all Beech woods. 


\section{(ii) Description of the Rough Down locality}

The collections from Rough Down were taken from a steep downside of short grazed turf. This colony is on the same escarpment as part of the Rockley population but is about a mile to the south-east of it. The two colonies are separated from one another by a road and a number of ploughed fields.

It will be seen from tables $I$ and 2 that the breeding communities in the beech wood areas have a much lower percentage of yellow shells than those living in the downland stations. This agrees with the results obtained by Cain and Sheppard (1950). Moreover, the intermediate types of habitat (area 3, which is a beech wood with a thick carpet of grass, and area 4, which is downland with some beech leaves on it) are intermediate with respect to the percentage of yellow shells in the populations.

The Rough Down colony also has a high proportion of yellow shells and agrees with the two Rockley downside communities.

\section{DISCUSSION}

Cain and Sheppard (1950) showed that there is a relationship between the ratio of the different colour and banding varieties in a population and the background on which it lives. They demonstrated that colonies living on a green background have a high proportion of yellow shells and the more discontinuous the background the higher the percentage of banited shells. Moreover, they suggested that snails with bands one and two absent are more unbanded than banded in appearance and should be classified as unbanded for ecological though not, of course, for genetical purposes. Lamotte (1950) has also shown that the different banded varieties can have different selective values but unlike Cain and Sheppard (1950) he believes that this selection is not usually of any importance (r $95 \mathrm{I}$ ).

The percentage of each of the three main colour phases (brown, pink and yellow) from the nine Rockley stations and Rough Down have been plotted on a triangular diagram (fig. 2). It will be seen that the samples from the bcech wood habitats (areas I, 2, 6, 8 and 9) fall into one group on the diagram, whereas those from the two Rockley downland areas and the Rough Down colony form another group. The two populations from the intermediate type of habitat (areas 3 and 4) fall between these two groups. Moreover, the proportion of yellow snails in the downland areas is significantly higher than in the beech wood habitats.

The correspondence between the proportion of the genetically determined colour varieties and the background on which the population lives can only be adequately explained by natural selection. Moreover, the results confirm the conclusions of Cain and Sheppard (1950) which were based on a comparison of samples from many different colonies. Furthermore, the divergence in the gene frequencies in the different collecting stations, within a single colony, as a result of natural selec- 


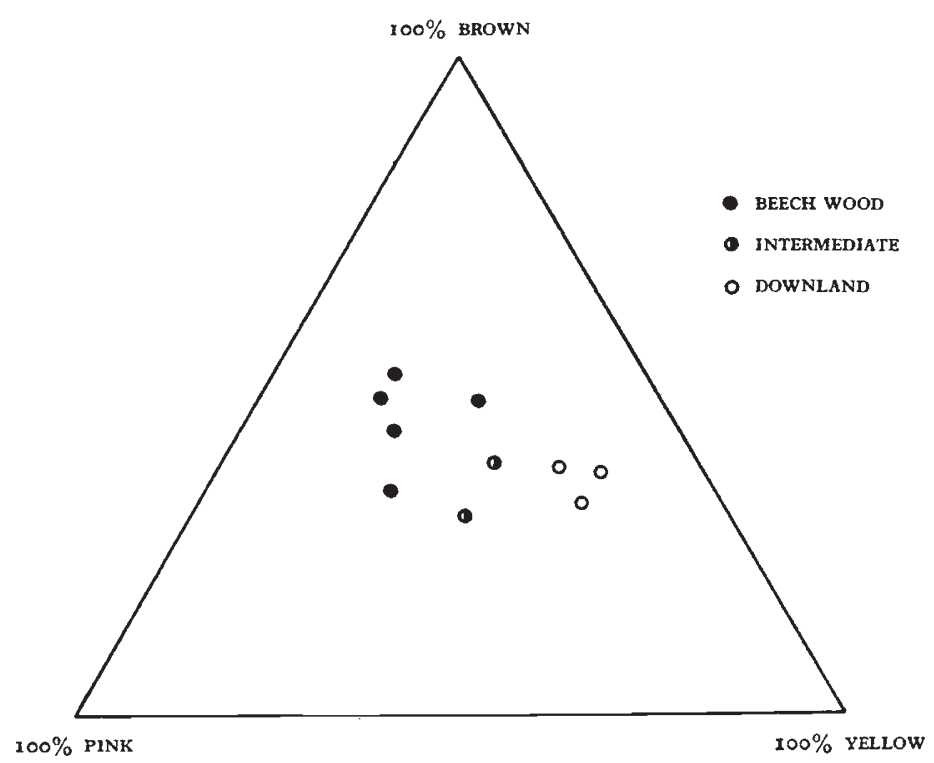

FIG. 2.- The triangular diagram shows the percentage of yellow, pink and brown shells in samples from the Rockley and Rough Down populations. Note that localities classified together because of their ecological similarity (downland, beech wood or intermediate) tend to group together.

tion, is in direct agreement with Diver's (1940) view that there is considerable isolation between the different parts of one colony as a result of distance. However, it contradicts his conclusion that the observed differences in the composition of breeding communities are the result of "genetic drift". Lamotte (195I) has estimated the effectiveness of isolation by distance in $C$. nemoralis and has arrived at a value for the size of the panmictic breeding unit, which would account for the amount of divergence found at Rockley if selection is intense.

It is probable that the intermediate values of the gene frequencies in areas 3 and 4 at Rockley are, in part, the result of incomplete isolation between the beech wood and downland habitats, as well as of the pressure of natural selection in the area itself. However, it is true to say that breeding communities in quite small parts of a continuously inhabited area can diverge from one another as the result of natural selection.

\section{SUMMARY}

1. The distribution of colour and banding varieties of the snail Cepaea nemoralis was investigated in two colonies at Rockley and Rough Down, a mile apart.

2. The Rough Down population lives in only one type of habitat. The population at Rockley extends over both downland and beech wood, and over two ecologically intermediate areas.

3. Three varieties, pink, brown and yellow, are found in all parts of the Rockley colony as well as at Rough Down. Their proportions 
in the two downland areas at Rockley and at Rough Down are similar, whereas the five beech wood stations have fewer yellows. The two intermediate habitats have an intermediate proportion of yellows.

4. Brceding communities within a colony of Cepaea can thus show differences in gene frequency as a result of isolation by distance. But the differences demonstrate the action of natural selection, not of "genetic drift"

\section{REFERENCES}

CAIn, A. J., AND Sheppard, P. M. I950. Selection in the Polymorphic Land Snail Cepaea nemoralis. Heredity, 4, 275-294.

DIVER, C. 1940. The Problem of closely related species living in the same area. The New Systematics, ed. Huxley, London, O.U.P.

FISHER, R. A., AND DIVER, C. I934. Crossing over in the Land Snail Cepaea nemoralis L. Nature, ${ }_{133}, 834$.

LAMOTrE, M. I950. Observations sur la sélection par les prédateurs chez Cepaea nemoralis. Fournal de Conchyliologie, 9o, 180-1 go.

i.Amotre, M. 195I. Résumés de Thèses. Recherches sur la structure génétique des populations naturelles de Cepaea nemoralis. Ann. Biol., 27, 39-49.

LANG, A. 1 go8. Ueber die Bastarde von Helix hortensis Müller und Helix nemoralis L. Festschr. Univ. Jena.

LANG, A. 1912. Vererbungswissenschaftliche Miszellen. Z.I.A.V., 8, 233-283.

SHEPPARD, P. M. I $95 \mathrm{I}$. Fluctuations in the selective value of certain phenotypes in the Polymorphic Land Snail, Cepaea nemoralis L. Heredity, 5, I25-134.

WRIGHr, s. 1940. Breeding structure of Populations in Relation to Speciation. Am. Nat., 74, 232-248.

Acknowledgments.-I am dceply indebted to Professor R. A. Fisher and Dr E. B. Ford both of whom read this paper in manuscript. Grateful acknowledgment is also made to the Department of Scientific and Industrial Research for a grant during the period of this investigation. 